\title{
Mineral-leaching chemical transport with runoff and sediment from severely eroded rare-earth tailings in southern China
}

\author{
Huizhong Lu ${ }^{1,2}$, Longxi Cao ${ }^{1}$, Yin Liang ${ }^{1}$, Jiuqin Yuan ${ }^{1,2}$, Yayun Zhu ${ }^{1,2}$, Yi Wang ${ }^{1,2}$, Yalan Gu ${ }^{1,2}$, and Qiguo Zhao ${ }^{1}$ \\ ${ }^{1}$ State Key Laboratory of Soil and Sustainable Agriculture, Institute of Soil Science, Chinese Academy of Sciences, \\ Nanjing 210008, China \\ ${ }^{2}$ University of Chinese Academy of Sciences, Beijing 100049, China
}

Correspondence to: Yin Liang (yliang@issas.ac.cn)

Received: 8 March 2017 - Discussion started: 20 March 2017

Revised: 4 July 2017 - Accepted: 15 July 2017 - Published: 23 August 2017

\begin{abstract}
Rare-earth mining has led to severe soil erosion in southern China. Furthermore, the presence of the mineral-leaching chemical ammonium sulfate in runoff and sediment poses a serious environmental threat to downstream water bodies. In this paper, the characteristics of mineral-leaching chemicals in surface soil samples collected in the field were studied. In addition, $\mathrm{NH}_{4}^{+}$and $\mathrm{SO}_{4}^{2-}$ transport via soil erosion was monitored using runoff and sediment samples collected during natural rainfall processes. The results demonstrated that the $\mathrm{NH}_{4}^{+}$contents in the surface sediment deposits increased from the top of the heap $\left(6.56 \mathrm{mg} \mathrm{kg}^{-1}\right)$ to the gully $\left(8.23 \mathrm{mg} \mathrm{kg}^{-1}\right)$ and outside the tailing heap $\left(13.03 \mathrm{mg} \mathrm{kg}^{-1}\right)$. The contents of $\mathrm{SO}_{4}^{2-}$ in the different locations of the tailing heaps ranged from 27.71 to $40.33 \mathrm{mg} \mathrm{kg}^{-1}$. During typical rainfall events, the absorbed $\mathrm{NH}_{4}^{+}$concentrations $\left(2.05,1.26 \mathrm{mg} \mathrm{L}^{-1}\right)$ in runoff were significantly higher than the dissolved concentrations $\left(0.93,1.04 \mathrm{mg} \mathrm{L}^{-1}\right)$, while the absorbed $\mathrm{SO}_{4}^{2-}$ concentrations $\left(2.87,1.92 \mathrm{mg} \mathrm{L}^{-1}\right)$ were significantly lower than the dissolved concentrations $\left(6.55,7.51 \mathrm{mg} \mathrm{L}^{-1}\right)$. The dissolved $\mathrm{NH}_{4}^{+}$and $\mathrm{SO}_{4}^{2-}$ concentrations in runoff displayed an exponentially decreasing tendency with increasing transport distance $(Y=1.02 \cdot \exp (-0.00312 X) ; Y=3.34$. $\exp (-0.0185 X))$. No clear trend with increasing distance was observed for the absorbed $\mathrm{NH}_{4}^{+}$and $\mathrm{SO}_{4}^{2-}$ contents in transported sediment. The $\mathrm{NH}_{4}^{+}$and $\mathrm{SO}_{4}^{2-}$ contents had positive correlations with the silt and clay ratio in transported sediment but negative correlations with the sand ratio. These results provide a better understanding of the transport processes and can be used to develop equations to predict the transport of mineral-leaching chemicals in rare-earth tailings,
\end{abstract}

which can provide a scientific foundation for erosion control and soil management in rare-earth tailing regions in southern China.

\section{Introduction}

Soil erosion is a global issue of great importance (Morgan, 2005) because it not only degrades soil quality but also leads to pollution associated with runoff and sediment, posing a risk to water and soil quality and human health. Humandriven production activities, especially mining, severely disturb the land and generate tailings, often leading to extremely serious soil erosion (Duque et al., 2015; Zhang et al., 2016; García-Gómez et al., 2014; Gharibreza et al., 2013; Meng et al., 2012; Riley, 1995). The soil erosion process in mining regions releases complex chemical substances into the surrounding environment, including nutrients, heavy metals, radioactive elements, and other contaminants, thereby threatening ecological security (Pascaud et al., 2015; Nascimento et al., 2012; Weng et al., 2012; Gao and Zhou, 2011; Mol and Ouboter, 2004; Razo et al., 2004).

The term "rare-earth element" (REE) refers to 17 elements containing lanthanide series along with scandium and yttrium (Khan et al., 2016). China is the dominant rare-earth element provider and accounts for over $95 \%$ of the world production (Tse, 2011). Southern China contains large amounts of lateritic ion-adsorption clay deposits, which are relatively enriched in heavy rare-earth elements (HREEs; Gao and Zhou, 2011). HREEs, which are widely used in aviation, electronics, transportation, and health care, have great signif- 
icance for industry and the economy (Kanazawa and Kamitani, 2006). The ion-adsorption deposits were formed by chemical weathering decomposition and dissolution of granite and granite porphyry (containing a relatively high abundance of REE) (Yang et al., 2013). The main ore body contains $0.05-0.2 \mathrm{wt} \%$ REE grades, and strong cerium anomalies are found. These ion-adsorption clay deposits have been mined since the 1970s. Thirty years of weakly regulated HREE mining have left a legacy of environmentally damaging accidents and contamination due to mining and ore processing (Kynicky et al., 2012). The regional humid subtropical climate and intense rainfall lead to considerable surface runoff, which leads to the erosion of tailings, high suspended sediment loads in streams, and subsequent sediment deposition. The soil erosion is extremely intensive, with an average annual value of approximately $3.8 \times 10^{4} \mathrm{t} \mathrm{km}^{-2} \mathrm{a}^{-1}$ ) (Lu et al., 2015), which far exceeds the severe erosion standard of $1.5 \times 10^{4} \mathrm{t} \mathrm{km}^{-2} \mathrm{a}^{-1}$ ) (SL190-2007, Ministry of Water Resources, PRC, 2008). In addition, as the HREEs are adsorbed onto the clay surface, large amounts of the mineralleaching chemicals are used to exchange the REE during ion-adsorption mining (Packey and Kingsnorth, 2016). The abandoned tailing heaps contain abundant acidic ammonium sulfate. These ions can lead to eutrophication in surface water, groundwater, and farmland, which are important for plant growth, animal livelihood, and human health in southern China (Zhang et al., 2016; Nie et al., 2009; Fu et al., 2004; Schlesinger et al., 2000; Schoumans et al., 2014; Tian et al., 2007; Gangbazo et al., 1995; Richardson and King, 1995; Lambert et al., 1985). Therefore, it is necessary to simulate and predict sediment yield and the leaching of chemical contents in rainfall runoff on and near the tailings.

Chemical transport during the erosion process is a complex process. This transport includes substance concentration variations, enrichment ratio variations, and both transport and transformation in runoff and sediment (Reddy and Patrick, 1984; Palis et al., 1990). It is influenced by many factors, such as rainfall intensity, runoff discharge, topography, soil characteristics, land use, vegetation cover, and anthropogenic or natural disturbances. Analysis of the chemical transport mechanism during the soil erosion process is very important for determining the potential chemical contents in both runoff and sediment. The methods used to study soil erosion and chemical transport include laboratory experiments, plot-based experiments, field observations, and watershed-level modeling (Lü et al., 2007). These methods have spatial scale differences, from the slope scale to the catchment scale (Palis et al., 1990; Razo et al., 2004; Ojeda et al., 2006; Zheng et al., 2016). Findings from small spatialscale experiments should be treated with caution when upscaling to describe chemical transport because they do not consider changes in the factors with increasing spatial scale. The simplified assumptions of models may fail to capture the chemical transport process, resulting in less accurate predictions of the chemical loads. Existing models, such as
AGNPS (Agricultural Non-Point-Source Pollution Model), CREAMS (Chemicals, Runoff, and Erosion from Agricultural Management Systems), and SWAT (Soil and Water Assessment Tool), calculate sediment yield based on the empirical USLE (Universal Soil Loss Equation) model, which does not include substance transport processes (Wu and Chen, 2012; Chaplot, 2005; West and Wali, 1999). In addition, the majority of the studies and models focus on non-point-source pollution in agricultural conditions, such as arable farming, tillage, and row cropping (Ongley et al., 2010). However, relatively few studies have focused specifically on extremely disturbed areas with intense rainfall. Therefore, our current knowledge of the chemical transportation process under serious erosional conditions is inadequate, especially in the lateritic ion-adsorption clay deposits of south China. The contamination situation is unclear, and the mechanism of mineral-leaching chemical transport during the soil erosion process has not been studied. As a large quantity of ammonium sulfate and ammonium bicarbonate were added in the production process, $\mathrm{NH}_{4}^{+}$and $\mathrm{SO}_{4}^{2-}$ still remain in the REE mining region. It is estimated that the process has generated about $20-25000 \mathrm{t}$ of wastewater and $300-500 \mathrm{mg} \mathrm{L}^{-1}$ total ammonia nitrogen concentration up until 2005 (Khan et al., 2016). $\mathrm{NH}_{4}^{+}$tends to adsorb onto soil, and excess $\mathrm{NH}_{4}^{+}$would accelerate soil acidification, reduce soil mineral element content, change soil solution ion composition, and aggravate the soil contamination (Zhou et al., 2014). $\mathrm{SO}_{4}^{2-}$ is water soluble, and a high concentration could lead directly to death for plants (Yang, 2009). Different chemicals have unique transportation pathways and primary carriers in runoff. Thus, it is necessary to compare the differences between $\mathrm{NH}_{4}^{+}$and $\mathrm{SO}_{4}^{2-}$.

The aim of a 2-year field study of runoff and sediment during natural rainfall events in a rare-earth tailing area was to (1) gain an insight into the two leaching chemicals' spatial distributions at different locations around the tailing heaps and (2) determine the transport characteristics and influencing factors of the two leaching chemicals in runoff, including both dissolved and adsorbed components.

\section{Materials and methods}

\subsection{Study area}

The experiment area is located in the Longshe soil erosion warning zone of rare-earth tailings (Fig. 1) in Xinfeng County, Ganzhou, Jiangxi Province, south China $\left(25^{\circ} 23^{\prime} 10^{\prime \prime} \mathrm{N}, 115^{\circ} 0^{\prime} 26^{\prime \prime} \mathrm{E}\right)$. The region features a subtropical moist monsoon climate with an average annual precipitation of $1500.4 \mathrm{~mm}$, nearly half of which occurs from April to June. The intense rainfall leads to severe soil erosion and substance loss. The annual runoff modulus is $874 \mathrm{~mm}$, and the total amount of annual runoff is approximately 5.2 billion $\mathrm{m}^{3}$. The mean annual temperature is $19.5^{\circ} \mathrm{C}$, with monthly 
(a)

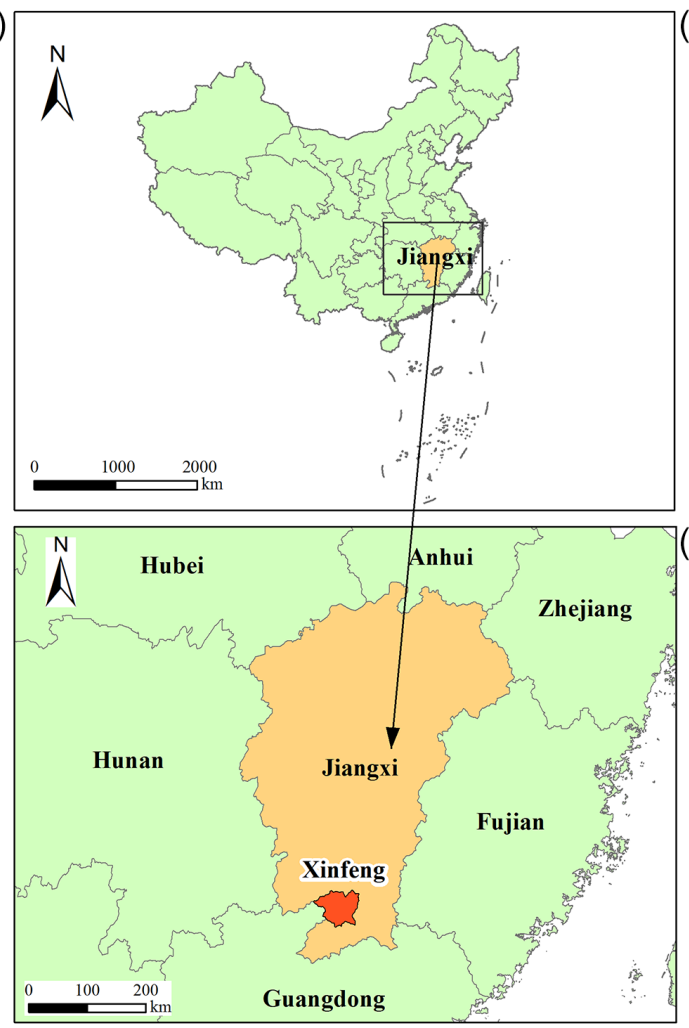

(b)

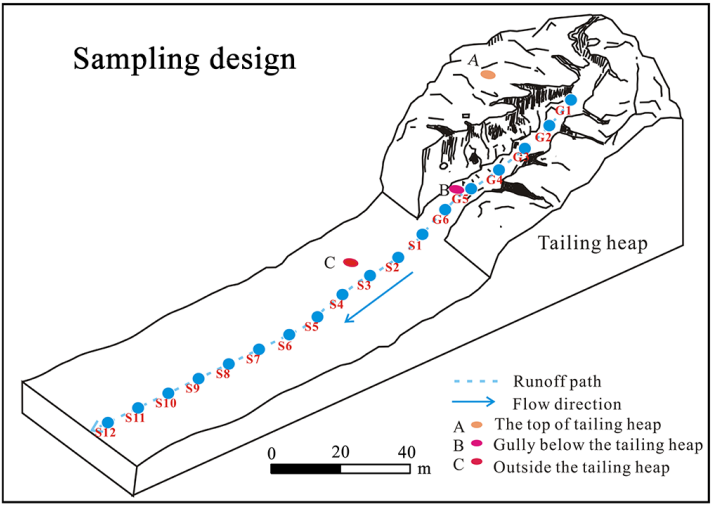

(c)

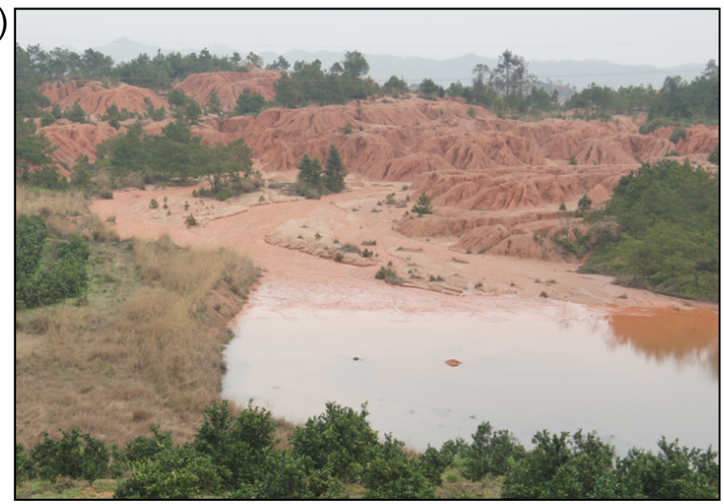

Figure 1. Study area (a), sampling design (b), and detailed view of the experimental area (c).

averages ranging from -4 to $39.4^{\circ} \mathrm{C}$. The pristine soils are red soils developed from weathered residual granite.

The tailing area is approximately $0.26 \mathrm{~km}^{2}$. The tailings were formed in 1986, and the height of the tailings range from 0.83 to $3.45 \mathrm{~m}$. A chain of undulating hills characterizes the topography due to mining and erosion. The mining technique for rare-earth ore is pond leaching, and ponding is one of the most prevalent mining methods. First, the subsurface ore body is mined, and the material is placed in an ammonium sulfate leaching pond to create a rare-earth solution. The REEs in the collected leaching solution are then precipitated with oxalic acid. Finally, the precipitates are turned into $\mathrm{R}_{2} \mathrm{O}_{3}$ via burning (Chi and Tian, 2007). After this mining process, residual tailing heaps containing acid leaching solution pollutants are formed. The production of $1 \mathrm{t}$ of rareearth oxide can create 1600-2000 t of tailings (Peng, 2005). There will be 302 abandoned mines and 191 million tons of tailings by 2020 in the Ganzhou region alone (Packey and Kingsnorth, 2016). No effective measures were taken, and the tailing heaps have experienced considerable soil loss. The tailing sediments in the region are poor in nutrients, strongly acidic, and subjected to substantial active erosion in areas where the original forest vegetation has been totally removed. Plants are rare, and only a few acid-resistant species, such as Dicranopteris and Pinus massoniana, are able to grow beside the tailing heaps. The tailing plots feature two major water erosion forms: gully erosion and slope erosion. The slope erosion can be divided into three types: slopes on the tailing heap surface, slopes in the gully below the tailing heap, and slopes outside the tailing heap. The average gully density is $0.13 \mathrm{~km} \mathrm{~km}^{-2}$, and the average gully sediment bulk density is $1.29 \mathrm{~g} \mathrm{~cm}^{-3}$.

\subsection{Sampling procedure}

We designed the sample paths and points based on the erosion types and flow direction. Figure 1 showed that one path along a gully $(\mathrm{G})$ and tailing heap (S) was designed. The G$S$ path was chosen because it had a relatively complete flow track, a long distance, and was not affected by other flow routes. The path length was $170 \mathrm{~m}$, and we set several sample points at intervals of $10 \mathrm{~m}$. The G-S path samples included natural rainfall runoff samples. Three rainfall events were recorded on 16 June 2012 and 15 and 16 May 2013. The precipitation intensities were measured with rainfall gauges and were $0.9,1.0$, and $1.2 \mathrm{~mm} \mathrm{~min}^{-1}$, respectively. These values are typical of the high intensities common during the rainy season in the red soil region in southern China (Ma et al., 2014). The runoff samples were collected close to the surface using pre-cleaned polyethylene bottles. The bottles were immediately placed in dark boxes and processed within $6 \mathrm{~h}$ of collection. At least two samples were taken at every sampling point. There were a total of 67 rainfall runoff samples. More- 
Table 1. $\mathrm{NH}_{4}^{+}$and $\mathrm{SO}_{4}^{2-}$ contents and soil textures in the surface soil samples collected in different locations. Locations $\mathrm{A}$, B and $\mathrm{C}$ are the top of the tailing heap, the gully below the tailing heap, and the area outside the tailing heap, respectively. The texture classification standard is according to the USDA (United States Department of Agriculture).

\begin{tabular}{lrr|rrrl}
\hline \multirow{2}{*}{ Locations } & $\mathrm{NH}_{4}^{+}$ & $\mathrm{SO}_{4}^{2-}$ & Sand 2-0.05 mm & Silt 0.05-0.002 mm & Clay $<0.002 \mathrm{~mm}$ & Soil texture \\
\cline { 2 - 6 } & \multicolumn{2}{c|}{$\mathrm{mg} \mathrm{kg}^{-1}$} & & $\%$ & \\
\hline $\mathrm{A}$ & $6.56 \pm 1.87$ & $40.33 \pm 4.58$ & $60.35 \pm 4.35$ & $36.07 \pm 4.26$ & $3.59 \pm 1.83$ & sandy loam \\
$\mathrm{B}$ & $8.23 \pm 1.46$ & $27.71 \pm 3.95$ & $92.63 \pm 1.31$ & $7.17 \pm 1.18$ & $0.20 \pm 0.19$ & sandy soil \\
$\mathrm{C}$ & $13.03 \pm 3.42$ & $32.11 \pm 4.42$ & $83.84 \pm 5.44$ & $15.56 \pm 5.19$ & $0.61 \pm 0.36$ & loamy sand \\
\hline
\end{tabular}

over, 20 surface sediment samples were collected on the top of the tailing heap (Fig. 1b), 6 deposited surface sediment samples were collected from the G path (G1-G6) (Fig. 1b) before the natural rainfall events, and 12 deposited surface sediment samples were collected from the S path (S1-S12) outside the tailing heap (Fig. 1b) after the rainfall events. All surface sediment samples were taken from 0 to $5 \mathrm{~cm}$ depths using small shovels and were stored in polyethylene bags. One sample was a mix of three parallel samples. The mixed surface sediment sample weight was approximately $500 \mathrm{~g}$.

\subsection{Analytical methods}

Runoff samples were measured as two phases, i.e., runoff water and sediment. The samples were filtered in the field with a $0.45 \mu \mathrm{m}$ pore-size membrane to separate the sediment from the water and measure dissolved and absorbed substances. Dissolved $\mathrm{NH}_{4}^{+}$and $\mathrm{SO}_{4}^{2-}$ concentrations and $\mathrm{pH}$ values were measured in the runoff water, and absorbed $\mathrm{NH}_{4}^{+}$and $\mathrm{SO}_{4}^{2-}$ contents, sediment concentrations, and particle distributions were measured in the runoff sediment samples. The precipitation intensities differed among the rainfall events, and the dissolved chemical concentrations increased with increasing precipitation intensity (Zhang et al., 2016). Thus, the data were standardized according to the precipitation intensities, i.e., the standardized concentrations were equal to the real concentrations divided by the corresponding precipitation intensity. The $\mathrm{NH}_{4}^{+}$and $\mathrm{SO}_{4}^{2-}$ contents and particle size distributions were also measured in the surface.

The $\mathrm{pH}$ values were determined using the glass calomel electrode method. The dissolved and absorbed $\mathrm{NH}_{4}^{+}$concentrations were analyzed colorimetrically using a flow injection analyzer. The dissolved and absorbed $\mathrm{SO}_{4}^{2-}$ concentrations were determined using turbidimetry through the formation of $\mathrm{BaSO}_{4}$ via the addition of $\mathrm{BaCl}_{2}$. The sediment particle distribution was determined by sieving in combination with the sieve-pipette method (Lu, 2000). Each sediment sample was divided into three sediment size groups: sand $(2-0.05 \mathrm{~mm})$, silt $(0.05-0.002 \mathrm{~mm})$, and clay $(<0.002 \mathrm{~mm})$.

\subsection{Data analysis}

One-way analysis of variance (ANOVA) was used to compare the difference between the leaching chemicals at different locations. Linear and nonlinear regressions were conducted to establish the relationship between the $\mathrm{NH}_{4}^{+}$and $\mathrm{SO}_{4}^{2-}$ concentrations and the influencing factors. The coefficient of determination $\left(R^{2}\right)$ was used to evaluate the performance of the applied regression equations. All of the analyses were performed using IBM SPSS statistics for Windows Version 19.0 (IBM Corp., Armonk, NY, USA), and all graphical displays were prepared using ORIGIN8.0 (OriginLab, Northampton, MA, USA) and ArcGIS 9.3 (ESRI, Redlands, CA, USA).

\section{Results}

\section{1 $\mathrm{NH}_{4}^{+}$and $\mathrm{SO}_{4}^{2-}$ spatial distributions in surface soils}

The $\mathrm{NH}_{4}^{+}$and $\mathrm{SO}_{4}^{2-}$ contents in surface runoff depends on the corresponding content in the tailing heaps. Therefore, the $\mathrm{NH}_{4}^{+}$and $\mathrm{SO}_{4}^{2-}$ content of surface sediments must be determined in different locations. Due to the long duration of runoff and sediment transportation, the surface sediment on the top of the tailing heap moved first to the gully below the tailing heap and then beyond the tailing heap along the flow direction (Fig. 1). Table 1 shows the average $\mathrm{NH}_{4}^{+}$and $\mathrm{SO}_{4}^{2-}$ contents in the surface sediment samples collected at different locations. From A to $\mathrm{B}$ and $\mathrm{C}$, the $\mathrm{NH}_{4}^{+}$contents increased. The value on top of the heap was $6.56 \mathrm{mg} \mathrm{kg}^{-1}$, and the values outside the heap reached as high as $13.03 \mathrm{mg} \mathrm{kg}^{-1}$. The trend observed for the $\mathrm{SO}_{4}^{2-}$ values did not agree with that of the $\mathrm{NH}_{4}^{+}$values. The $\mathrm{SO}_{4}^{2-}$ content was highest on top of the tailing heap, lowest in the gully below the tailing heap, and intermediate outside of the tailing heap. The $\mathrm{SO}_{4}^{2-}$ content in the gully below the tailing heap was similar to that outside the tailing heap. The different sediment particle distributions led to different textures in the three locations (Table 1). The sediment on top of the tailing heap had the highest silt and clay contents, and its texture was sandy loam. The texture in the gully below the tailing heap was sandy soil be- 
cause the sand content exceeded $90 \%$. Similarly, the texture outside the tailing heap was loamy sand. The texture difference between positions $\mathrm{A}, \mathrm{B}$, and $\mathrm{C}$ might be due to the long period of time associated with the runoff process.

\subsection{Dissolved and absorbed $\mathrm{NH}_{4}^{+}$and $\mathrm{SO}_{4}^{2-}$ concentrations in runoff}

Dissolved and absorbed $\mathrm{NH}_{4}^{+}$and $\mathrm{SO}_{4}^{2-}$ concentrations in the runoff samples at different locations can be found in Table 2. Runoff is the main driving force for soil erosion and chemical transport. In the case of runoff movement, the chemicals adsorbed onto the sediment particles enter overland flow. Additionally, the dissolved chemicals also enter the sediment surface. After more than 20 years of leaching and weathering, the runoff was still acidic. The runoff $\mathrm{pH}$ values were nearly the same at locations $\mathrm{B}$ (4.51) and $\mathrm{C}$ (4.56). The results of the ANOVA (Table 2) indicated that highly significant differences were observed between the dissolved and absorbed leaching chemicals. The absorbed $\mathrm{NH}_{4}^{+}$ concentrations at sites $\mathrm{B}\left(2.05 \mathrm{mg} \mathrm{L}^{-1}\right)$ and $\mathrm{C}\left(1.26 \mathrm{mg} \mathrm{L}^{-1}\right)$ were significantly higher than the dissolved $\mathrm{NH}_{4}^{+}$contents at sites $\mathrm{B}\left(0.93 \mathrm{mg} \mathrm{L}^{-1}\right)$ and $\mathrm{C}\left(1.04 \mathrm{mg} \mathrm{L}^{-1}\right)$, respectively (ANOVA, $p=0.001$ and $p=0.000$ ). This phenomenon shows that $\mathrm{NH}_{4}^{+}$was mainly transported by sediment in the runoff. In addition, the dissolved $\mathrm{SO}_{4}^{2-}$ concentrations at sites $\mathrm{B}\left(6.55 \mathrm{mg} \mathrm{L}^{-1}\right)$ and $\mathrm{C}\left(7.51 \mathrm{mg} \mathrm{L}^{-1}\right)$ were significantly greater than the absorbed $\mathrm{SO}_{4}^{2-}$ at sites $\mathrm{B}\left(2.87 \mathrm{mg} \mathrm{L}^{-1}\right)$ and $\mathrm{C}\left(1.92 \mathrm{mg} \mathrm{L}^{-1}\right)$, respectively (ANOVA, $p=0.001$ and $p=0.000$ ). It is evident that $\mathrm{SO}_{4}^{2-}$ was mainly transported in runoff. The primary transportation mechanisms for $\mathrm{NH}_{4}^{+}$ and $\mathrm{SO}_{4}^{2-}$ in runoff were different. Moreover, the dissolved $\mathrm{NH}_{4}^{+}$and $\mathrm{SO}_{4}^{2-}$ concentrations $\left(0.93\right.$ and $\left.6.55 \mathrm{mg} \mathrm{L}^{-1}\right)$ at location $\mathrm{B}$ were smaller than those at location $\mathrm{C}(1.04$ and $7.51 \mathrm{mg} \mathrm{L}^{-1}$ ), whereas the absorbed $\mathrm{NH}_{4}^{+}$and $\mathrm{SO}_{4}^{2-}$ concentrations at location $\mathrm{B}\left(2.05\right.$ and $\left.2.87 \mathrm{mg} \mathrm{L}^{-1}\right)$ were greater than those at location $\mathrm{C}\left(1.26\right.$ and $\left.1.92 \mathrm{mg} \mathrm{L}^{-1}\right)$. This pattern is likely due to enrichment of the mineral-leaching chemicals in the gully and lower enrichment ratios outside of the gully. However, only absorbed $\mathrm{NH}_{4}^{+}$concentrations displayed significant differences at location B and C (ANOVA, $p=0.04)$. The gully sediment concentration $\left(288.29 \mathrm{~g} \mathrm{~L}^{-1}\right)$ was also significantly greater than that outside the gully $\left(157.28 \mathrm{~g} \mathrm{~L}^{-1}\right)$ (ANOVA, $p=0.01$ ).

\subsection{Dissolved and absorbed $\mathrm{NH}_{4}^{+}$and $\mathrm{SO}_{4}^{2-}$ transport characteristics along flow route}

Data for the two rainfall days in 2013 were used for a trend analysis. The dissolved $\mathrm{NH}_{4}^{+}$transportation characteristics are shown in Fig. 2a. We took the representative $\mathrm{G}-\mathrm{S}$ path as an example to analyze the transport characteristics. The $\mathrm{NH}_{4}^{+}$concentrations gradually decreased with transport distance along the sample path. Exponential functions were used to fit the tendency because the concentrations approached 0 at long distances. The dissolved $\mathrm{NH}_{4}^{+}$concentrations decreased exponentially $(Y=1.023 \cdot \exp (-0.00312 X)$; $\left.R^{2}=0.57\right)$ as a function of the transport distance along the $\mathrm{G}-\mathrm{S}$ path. The dissolved $\mathrm{SO}_{4}^{2-}$ transport trend was consistent with that of $\mathrm{NH}_{4}^{+}$in the sampled runoff. Figure $2 \mathrm{~b}$ shows the $\mathrm{SO}_{4}^{2-}$ migration. The $\mathrm{SO}_{4}^{2-}$ concentrations also decreased exponentially $\left(Y=3.34 \cdot \exp (-0.0185 X) ; R^{2}=\right.$ 0.57 ) with increasing transport distance along the G-S path. However, the relationships for $\mathrm{NH}_{4}^{+}$and $\mathrm{SO}_{4}^{2-}$ transport differed. The dissolved $\mathrm{NH}_{4}^{+}$concentrations ranged from 0.45 to $1.17 \mathrm{mg} \mathrm{L}^{-1}$, while the dissolved $\mathrm{SO}_{4}^{2-}$ concentrations ranged from 2.19 to $3.45 \mathrm{mg} \mathrm{L}^{-1}$. Moreover, the attenuation coefficients of the $\mathrm{SO}_{4}^{2-}$ transport fit (3.34 and 0.0185) were greater than those of $\mathrm{NH}_{4}^{+}$(1.023 and 0.00312), indicating that the $\mathrm{SO}_{4}^{2-}$ concentrations decreased faster than the $\mathrm{NH}_{4}^{+}$ concentrations.

The absorbed $\mathrm{NH}_{4}^{+}$and $\mathrm{SO}_{4}^{2-}$ transport was influenced not only by precipitation intensity and flow energy but also by the erosion amount and sediment transport capacity. The sediment runoff process was so complex that a standardization of $\mathrm{NH}_{4}^{+}$and $\mathrm{SO}_{4}^{2-}$ concentrations using precipitation intensities was impossible. Thus, rainfall data for 15 May 2013, were used as an example to analyze the absorbed chemicals in the runoff sediment samples. The absorbed $\mathrm{NH}_{4}^{+}$transport characteristics are shown in Fig. 3a. Initially (transport distance 0-120 m), the absorbed $\mathrm{NH}_{4}^{+}$concentrations showed a weak descending trend. However, when the sediment moved beyond $120 \mathrm{~m}$, the concentrations increased to a distance of $180 \mathrm{~m}$. Figure $3 \mathrm{~b}$ show that the absorbed $\mathrm{SO}_{4}^{2-}$ transport was quite different from that of $\mathrm{NH}_{4}^{+}$in the sampled runoff sediment. The absorbed $\mathrm{SO}_{4}^{2-}$ concentrations exhibited substantial variability as a function of the transport distance. The transport characteristics of the adsorbed $\mathrm{NH}_{4}^{+}$and $\mathrm{SO}_{4}^{2-}$ in the runoff sediment cannot be described as a linear function because it is difficult to identify a distinct trend.

\subsection{Variations in absorbed $\mathrm{NH}_{4}^{+}$and $\mathrm{SO}_{4}^{2-}$ contents with sand, silt, and clay particles}

The grain size analysis was carried out in order to find correlation between leaching chemicals and the sediment particle size distributions. Figures 4 and 5 showed that the absorbed $\mathrm{NH}_{4}^{+}$and $\mathrm{SO}_{4}^{2-}$ concentrations in the sampled runoff exhibited similar relationships with the sediment particle size distribution. The $\mathrm{NH}_{4}^{+}$and $\mathrm{SO}_{4}^{2-}$ content displayed linearly decreasing trends with increasing sand content and linearly increasing trends with increasing silt and clay contents.

\section{Discussion}

In this paper, to study the transport characteristics of mineralleaching chemicals, soil on rare-earth tailings was sam- 
Table 2. Average dissolved and absorbed $\mathrm{NH}_{4}^{+}$and $\mathrm{SO}_{4}^{2-}$ concentrations in the runoff samples at different locations. Locations $\mathrm{B}$ and $\mathrm{C}$ represent the gully below the tailing heap and outside the tailing heap, respectively. The asterisk refers to the very significant difference between the two statuses (dissolved and absorbed) of the same chemical at the same location at the 0.01 level.

\begin{tabular}{lrrrr|rrr}
\hline Positions & $\begin{array}{r}\text { Dissolved } \\
\mathrm{NH}_{4}^{+}\end{array}$ & $\begin{array}{r}\text { Absorbed } \\
\mathrm{NH}_{4}^{+}\end{array}$ & $\begin{array}{r}\text { Dissolved } \\
\mathrm{SO}_{4}^{2-}\end{array}$ & $\begin{array}{r}\text { Absorbed } \\
\mathrm{SO}_{4}^{2-}\end{array}$ & $\begin{array}{r}\text { Runoff } \\
\text { volume }\end{array}$ & $\begin{array}{r}\text { Sediment } \\
\text { concentration }\end{array}$ & $\begin{array}{r}\text { Runoff } \\
\mathrm{pH}\end{array}$ \\
\cline { 2 - 8 } & \multicolumn{7}{c}{$\mathrm{mg} \mathrm{L}^{-1}$} \\
$\mathrm{~B}$ & 0.93 & $2.05^{*}$ & 6.55 & $2.87^{*}$ & 0.37 & 288.29 & 4.51 \\
$\mathrm{C}$ & 1.04 & $1.26^{*}$ & 7.51 & $1.92^{*}$ & 0.39 & 157.28 & 4.56 \\
\hline
\end{tabular}

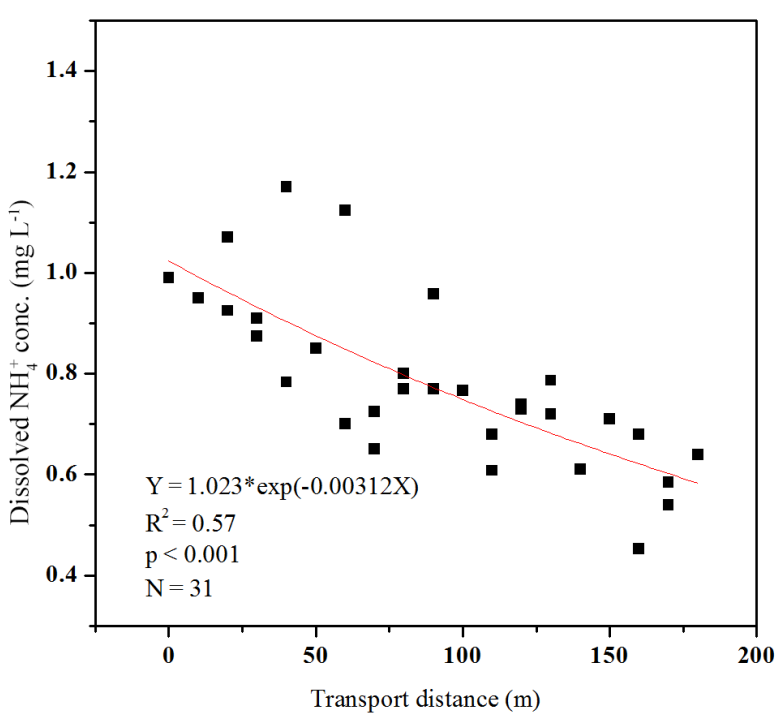

(a)

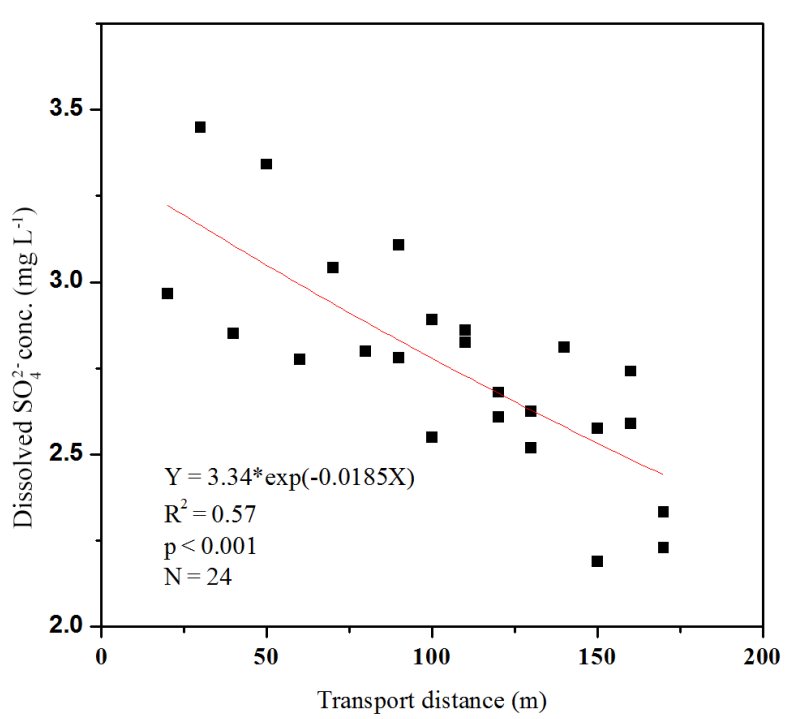

(b)

Figure 2. Dissolved $\mathrm{NH}_{4}^{+}$and $\mathrm{SO}_{4}^{2-}$ concentrations variations with increasing transport distance in runoff.

pled in different positions, and runoff and sediment samples were collected along flow routes during three typical rainfall events in the field. The results revealed the mineralleaching chemicals' spatial distributions driving mechanism and transportation dynamic in flow and sediment processes.

\subsection{The driving mechanism of the $\mathrm{NH}_{4}^{+}$and $\mathrm{SO}_{4}^{2-}$ spatial distributions}

This study examined the transportation characteristics of $\mathrm{NH}_{4}^{+}$and $\mathrm{SO}_{4}^{2-}$ in runoff in order to explain their distribution in the surface soil at different locations. The main carrier mechanism is an important factor influencing chemical contents along the transport path. $\mathrm{NH}_{4}^{+}$was mainly transported with the sediment in the runoff (Table 2), which was especially enriched in fine particles (Fig. 4). It is possible that $\mathrm{NH}_{4}^{+}$has a strong affinity to the negatively charged particles (Tian et al., 2007). The $\mathrm{NH}_{4}^{+}$contents exhibited an increasing trend from the top of the tailing heap to beyond the heap (Table 1). Similar results have been reported by other studies. Particulate $\mathrm{N}$ was the main form in runoff in some ecosystems (Douglas et al., 1998; Zheng et al., 2005). Zhang and
Shao (2000) revealed that $\mathrm{NH}_{4}^{+}$was mainly adsorbed onto soil particles, whereas nitrate $\mathrm{N}$ may more easily exist in soil solution. Zheng et al. (2005) also found that $\mathrm{NH}_{4}^{+}$was concentrated in clay, which was transported with the eroded sediment in newly deforested areas on the Loess Plateau. However, our results differ from those of Fu et al. (2004), who reported that $\mathrm{NH}_{4}^{+}$is mainly transported in its dissolved form in runoff. Differences in land use, especially tillage and fertility management, may be responsible for these differences.

The main transport medium of $\mathrm{SO}_{4}^{2-}$ was runoff, and Table 2 demonstrated that $\mathrm{SO}_{4}^{2-}$ moved primarily in a dissolved state, which resulted in a non-significant transport trend from locations $\mathrm{A}$ to $\mathrm{C}$ in deposited sediment (Table 1). Our results demonstrate that $\mathrm{SO}_{4}^{2-}$ absorption occurred rarely in the upper soil; Alewell and Giesemann (1996) also reported that $\mathrm{SO}_{4}^{2-}$ sorption was not observed in the upper soil $(\leq 1 \mathrm{~m}$ depth), and $\mathrm{SO}_{4}^{2-}$ solutions may have infiltrated from upper soil layers into deeper soil layers (1-12 $\mathrm{m}$ depth), where more $\mathrm{SO}_{4}^{2-}$ sorption was present. The dissolved $\mathrm{SO}_{4}^{2-}$ concentration may be related to $\mathrm{pH}$ values. Sharpley et al. (1991) conducted a 4-year field experiment to study the $\mathrm{SO}_{4}^{2-}$ transport 


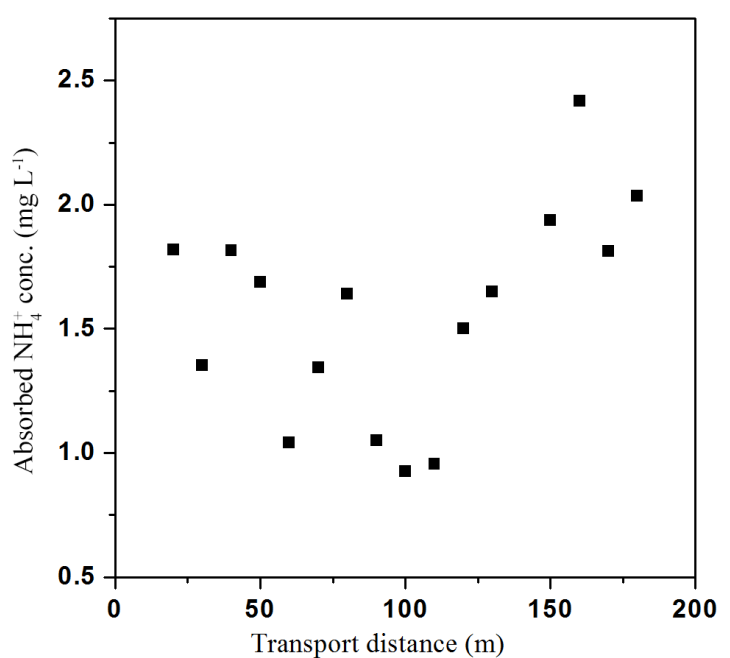

(a)

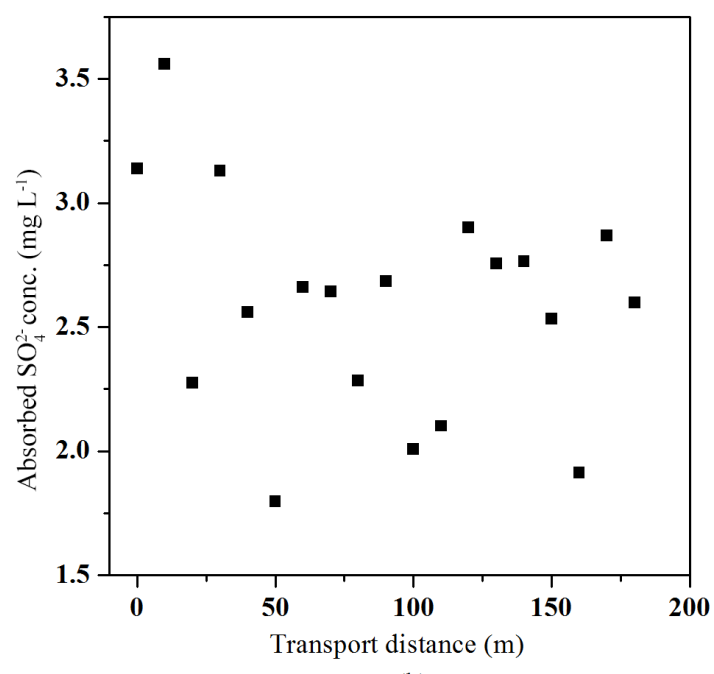

(b)

Figure 3. Absorbed $\mathrm{NH}_{4}^{+}$and $\mathrm{SO}_{4}^{2-}$ concentrations variations with increasing transport distance in runoff.

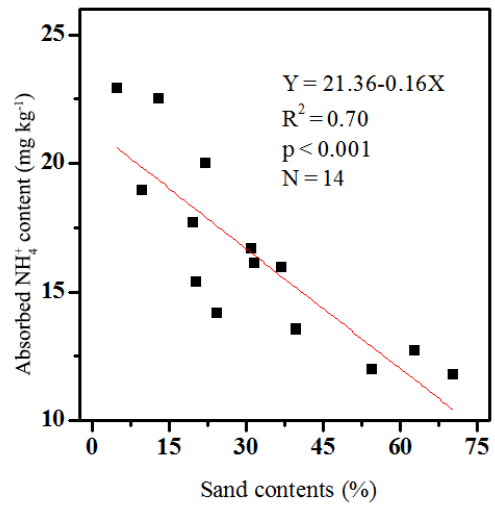

(a)

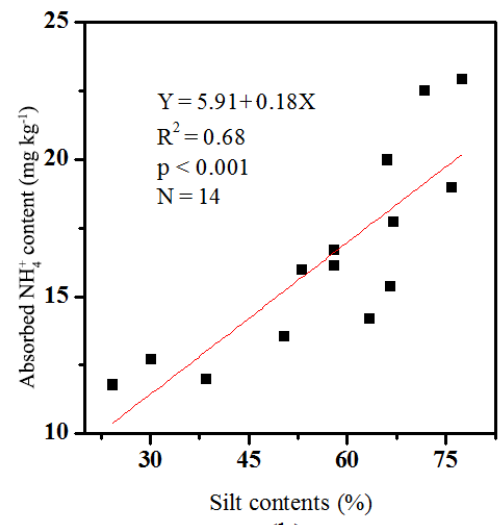

(b)

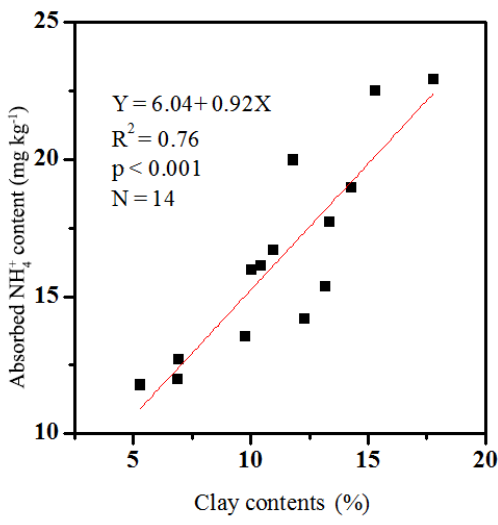

(c)

Figure 4. Absorbed $\mathrm{NH}_{4}^{+}$concentrations as a function of sand, silt, and clay contents.

in runoff and reported that the $\mathrm{SO}_{4}^{2-}$ concentration increases with decreasing $\mathrm{pH}$ in runoff.

\section{2 $\mathrm{NH}_{4}^{+}$and $\mathrm{SO}_{4}^{2-}$ transport dynamic in flow and sediment process}

Although the main pattern of transport differed between $\mathrm{NH}_{4}^{+}$and $\mathrm{SO}_{4}^{2-}$ in the runoff, the total concentrations involved both dissolved and absorbed states. The release of chemicals to the runoff involves the adsorption and desorption between the sediment surface and their transport by advection or by ordinary or enhanced diffusion (Wallach et al., 1989). The dissolved $\mathrm{NH}_{4}^{+}$and $\mathrm{SO}_{4}^{2-}$ decreased exponentially during the runoff transport process (Fig. 2) because the dilution associated with increasing runoff discharge and flow diffusion dominated the dissolved chemical transport under these conditions. Schlesinger et al. (2000) reported that the concentrations of dissolved constituents declined with in- creasing total runoff volume, reflecting a rapid dilution of dissolved constituents with increasing discharge. Razo et al. (2004) also observed an inverse relationship between the distance and the concentration of metals in water from the pollution sources. However, the dissolved $\mathrm{SO}_{4}^{2-}$ concentration decreased faster than that of $\mathrm{NH}_{4}^{+}$, which was probably because dissolved $\mathrm{SO}_{4}^{2-}$ was mainly transported in runoff water. Thus, runoff discharge had a larger influence on the dissolved $\mathrm{SO}_{4}^{2-}$ transportation. Abu Bakar et al. (2015) found $\mathrm{SO}_{4}^{2-}$ was diluted by the large amounts of water observed during high-flow events. In addition, the chemical desorption kinetics, which may be limited by the contact time and sediment surface, should be an important control for dissolved chemicals in runoff (Gilley et al., 2012).

The absorbed $\mathrm{NH}_{4}^{+}$and $\mathrm{SO}_{4}^{2-}$ transport was more complicated in the runoff sediment. Tailing heaps provided a large quantity of sediments to the gully at the beginning of erosion. 


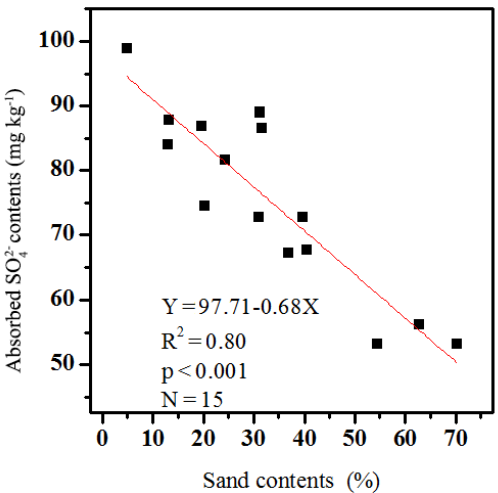

(a)

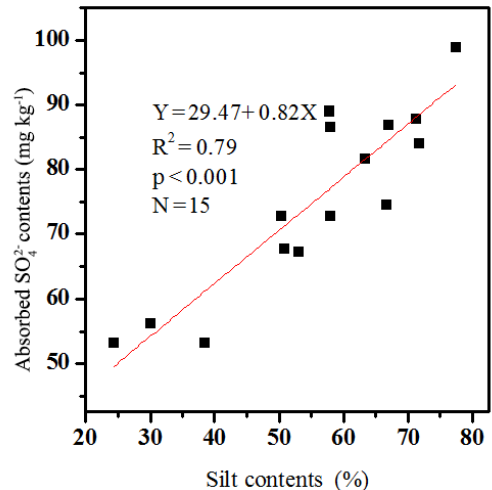

(b)

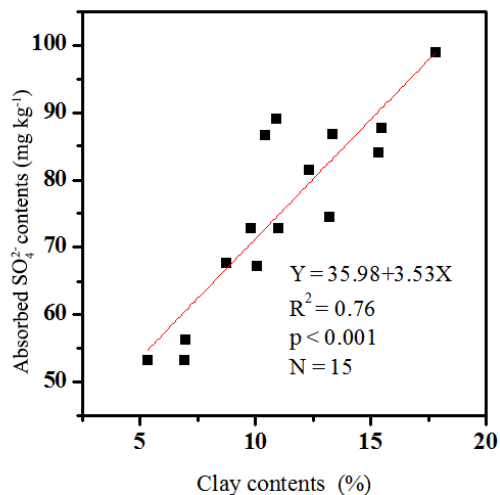

(c)

Figure 5. Absorbed $\mathrm{SO}_{4}^{2-}$ concentrations as a function of sand, silt, and clay contents.

Thus, the sediment concentration and the absorbed leaching chemicals continued to accumulate. When the runoff and runoff-associated sediment flowed beyond the heaps, the sediment concentration exceeded the runoff transport capacity as the flow decreased, resulting in gradual deposition of the sediment. Accordingly, the sediment concentration and absorbed $\mathrm{NH}_{4}^{+}$and $\mathrm{SO}_{4}^{2-}$ concentrations decreased (Table 2). As mentioned above, $\mathrm{NH}_{4}^{+}$was transported in an absorbed state on fine particles (Fig. 4). Finer particles, especially clay, are typically considered to be the sediment size fraction that is most important in transporting adsorbed chemicals in soil and overland flow (Slattery and Burt, 1997; Young and Onstad, 1978; Hardy et al., 2016). Smaller particles, particularly silt and clay, have relatively greater specific surface areas and can therefore adsorb and transport large quantities of chemicals (Lü et al., 2007). Finer particles are more easily transported in runoff, resulting in increased fine-particle levels with transport distance along the path (Flanagan and Nearing, 2000; Parsons et al., 2006). More finer sediment reached the end of the deposition region than did coarser particles, and more chemicals were absorbed on fine sediment particles. This is known as the selectivity of the erosion process (Sharpley, 1985; Zhang et al., 2016). Although the absolute quantity of sediment decreased, the percentage of relatively fine particles increased. This process explains why the absorbed $\mathrm{NH}_{4}^{+}$transport characteristics in runoff showed an increasing trend over the last several meters (120$180 \mathrm{~m}$; Fig. 3a). The trend slightly decreased at first; thus, the dynamic accumulation, remobilization, and absorptiondesorption in the transport process may influence the absorbed $\mathrm{NH}_{4}^{+}$trend over the first few tens of meters (Ashraf and Borah, 1992; Huang et al., 2007). Although the absorbed $\mathrm{SO}_{4}^{2-}$ concentration in the runoff also increased with finer particles and decreased with more sand particles (Fig. 5), the dissolved state is the major $\mathrm{SO}_{4}^{2-}$ transport form. The reason for this may differ from that for $\mathrm{NH}_{4}^{+}$, which was mainly transported in its absorbed state. Flow energy attenuation may also have enriched finer particles in absorbed $\mathrm{SO}_{4}^{2-}$ in the sampled runoff. The $\mathrm{SO}_{4}^{2-}$ continuously dissolved in the runoff and infiltrated into deeper soil layers; hence, the absorbed $\mathrm{SO}_{4}^{2-}$ concentrations were highly variable with distance (Fig. 3b). No clear transport features exist for absorbed chemical in the sampled runoff. Pascaud et al. (2015) found that the effect of mining contamination decreased in sediment over a distance of $8000 \mathrm{~m}$. Our study scale may not be large enough; moreover, earlier deposited sediment may have affected the runoff samples.

\subsection{Implications and prospects of this study}

The mineral-leaching chemicals' characteristics in rare-earth tailing heaps were discussed in this study. The results of this study indicate that leaching chemicals $\left(\mathrm{NH}_{4}^{+}\right.$and $\left.\mathrm{SO}_{4}^{2-}\right)$ transport characteristics as dissolved and absorbed state in runoff and sediment along the flow route during natural rainfall. Besides the leaching chemicals we found, $\mathrm{Pb}, \mathrm{Cd}, \mathrm{Zn}$, $\mathrm{Cu}$ and radioactive elements also existed (Gao and $\mathrm{Zhou}$, 2011). The pollutants were transported from the mining area to the surrounding soil and surface water bodies through surface runoff water. Even after mining activities stopped, the ecological environment may still suffer a series of serious problems, such as the loss of farmland by sediment deposition due to soil erosion and damaged soil because of low $\mathrm{pH}$ and high chemical concentration. Measures for soil erosion and soil remediation must be urgently taken within the mining area. Vegetation and mulches have been proved to effectively reduce runoff energy and trap sediment (Cao et al., 2015). Meanwhile, ditches and terracing should also be conducted to intercept runoff. Soil amendment and fertility can be applied to improve the soil quality. These practices may control the influence of leaching chemicals, rare-earth elements, and sediments on the surrounding environment. Furthermore, there are also many other factors that influence pollutant transport behavior besides transport distance, e.g., the flow energy and topography factors. In future research, field- 
simulated experiments should be conducted to establish the relationship between flow hydraulic parameters and chemical transport characteristics. All of these studies may provide a scientific foundation for erosion control and soil management in rare-earth tailing regions in southern China.

\section{Conclusions}

Large amounts of mineral-leaching chemicals $\left(\mathrm{NH}_{4}^{+}\right.$and $\mathrm{SO}_{4}^{2-}$ ) were still remaining in rare-earth tailings in southern China. By collecting field runoff samples during typical rainfall events in a rare-earth tailing area, this study assessed the contents of two mineral-leaching chemicals in surface sediments at different positions and provided insights regarding runoff- and sediment-related transport characteristics along the flow route. During typical rainfall events, the absorbed $\mathrm{NH}_{4}^{+}$concentrations in runoff were significantly higher than the dissolved concentrations, while the absorbed $\mathrm{SO}_{4}^{2-}$ concentrations were significantly lower than the dissolved concentrations. The driving mechanism of the $\mathrm{NH}_{4}^{+}$ and $\mathrm{SO}_{4}^{2-}$ resulted in their spatial distributions in different locations. $\mathrm{NH}_{4}^{+}$is mainly transported with sediment in an absorbed state, and $\mathrm{NH}_{4}^{+}$content in the surface sediment samples showed an increasing trend from the top of the tailing heap to the area beyond the tailing gullies. Whereas $\mathrm{SO}_{4}^{2-}$ is mainly dissolved and transported with runoff, the $\mathrm{SO}_{4}^{2-}$ content did not show an observable trend. The dissolved $\mathrm{NH}_{4}^{+}$ and $\mathrm{SO}_{4}^{2}$ concentrations in runoff showed exponentially decreasing trends with transport distance from gully outlets to the nearby water body as a result of dilution. The absorbed chemicals' transport process may be more complex. The absorbed $\mathrm{NH}_{4}^{+}$and $\mathrm{SO}_{4}^{2-}$ concentrations in runoff showed no clear trends with transport distance. Linear regressions were conducted to establish the relationship between the $\mathrm{NH}_{4}^{+}$and $\mathrm{SO}_{4}^{2-}$ concentrations and the sand, silt, and clay contents. The $\mathrm{NH}_{4}^{+}$and $\mathrm{SO}_{4}^{2}$ concentrations tended to be enriched in the silt and clay particles of transported sediment. The above results will aid a better understanding of the transport characteristics of mineral-leaching chemicals during the erosion process and the development of predictive equations in rare-earth tailing areas. Our results suggest that management practices for soil remediation should be mandatory in rareearth tailings in southern China.

Data availability. All data obtained can be accessed by e-mailing the first author (hzlu@issas.ac.cn).

The Supplement related to this article is available online at https://doi.org/10.5194/se-8-845-2017-supplement.
Author contributions. LC, HL, and YL designed the research sample methods. LC, HL, JY, YZ, YW, and YG carried them out in the field. HL, LC, and YL developed the model code and performed the simulations. HL and LC prepared the paper. QZ and YL provided constructive suggestions for the paper.

Competing interests. The authors declare that they have no conflict of interest.

Acknowledgements. This work was supported by the ISSCAS Innovation Program (grant number ISSASIP1116), the National Natural Science Foundation of China (grant number 41571273), and the Key Technologies Research and Development Program of China (grant number 2014BAD15B03-2).

Edited by: Martine van der Ploeg

Reviewed by: two anonymous referees

\section{References}

Abu Bakar, A. F., Yusoff, I., Ng, T. F., and Ashraf, M. A.: Cumulative impacts of dissolved ionic metals on the chemical characteristics of river water affected by alkaline mine drainage from the Kuala Lipis gold mine, Pahang, Malaysia, Chem. Ecol., 31, 22-33, 2015.

Alewell, C. and Giesemann, A.: Sulfate reduction in a forested catchment as indicated by $\delta(34) \mathrm{S}$ values of sulfate in soil solutions and runoff, Isot. Environ. Health Stud., 32, 203-210, 1996.

Ashraf, M. S. and Borah, D. K.: Modeling pollutant transport in runoff and sediment, Trans. ASAE, 35, 1789-1797, 1992.

Cao, L., Zhang, Y. G., Lu, H. Z., Yuan, J. Q., Zhu, Y. Y., and Liang, Y.: Grass hedge effects on controlling soil loss from concentrated flow: A case study in the red soil region of China, Soil Till. Res., 148, 97-105, 2015.

Chaplot, V.: Impact of DEM mesh size and soil map scale on SWAT runoff, sediment, and NO 3-N loads predictions, J. Hydrol., 312, 207-222, 2005.

Chi, R. A. and Tian, J.: Review of weathered crust rare earth ore, J. Chin. Rare Earth Soc., 25, 641-650, 2007 (in Chinese with English Abstract).

Douglas, C. L., King, K. A., and Zuzel, J. F.: Nitrogen and phosphorus in surface runoff and sediment from a wheat-pea rotation in northeastern Oregon, J. Environ. Qual., 27, 1170-1177, 1998.

Duque, J. M., Zapico, I., Oyarzun, R., García, J. L., and Cubas, P.: A descriptive and quantitative approach regarding erosion and development of landforms on abandoned mine tailings: new insights and environmental implications from SE Spain, Geomorphology, 239, 1-16, 2015.

Flanagan, D. C. and Nearing, M. A.: Sediment particle sorting on hillslope profiles in the WEPP model, Trans. ASAE, 43, 573583, 2000.

Fu, B. J., Meng, Q. H., Qiu, Y., Zhao, W. W., Zhang, Q. J., and Davidson, D. A.: Effects of land use on soil erosion and nitrogen loss in the hilly area of the Loess Plateau, China, Land Degrad. Dev., 15, 87-96, 2004. 
Gangbazo, G., Pesant, A. R., Barnett, G. M., Charuest, J. P., and Cluis, D.: Water contamination by ammonium nitrogen following the spreading of hog manure and mineral fertilizers, J. Environ. Qual., 24, 420-425, 1995.

Gao, Z. Q. and Zhou, Q. X.: Contamination from rare earth ore strip mining and its impacts on resources and eco-environment, J. Ecol., 30, 2915-2922, 2011 (in Chinese with English Abstract).

García-Gómez, C., Sánchez-Pardo, B., Esteban, E., Peñalosa, J. M., and Fernández, M. D.: Risk assessment of an abandoned pyrite mine in Spain based on direct toxicity assays, Sci. Total Environ., 470-471, 390-399, 2014.

Gharibreza, M., Raj, J. K., Yusoff, I., Othman, Z., Tahir, W. Z. W. M., and Ashraf, M. A.: Historical variations of Bera Lake (Malaysia) sediments geochemistry using radioisotopes and sediment quality indices, J. Radioanal. Nucl. Ch., 295, 1715-1730, 2013.

Gilley, J. E., Vogel, J. R., Eigenberg, R. A., Marx, D. B., and Woodbury, B. L.: Nutrient losses in runoff from feedlot surfaces as affected by unconsolidated surface materials, J. Soil Water Conserv., 67, 11-17, 2012.

Hardy, R. A., Pates, J. M., Quinton, J. N., and Coogan, M. P.: A novel fluorescent tracer for real-time tracing of clay transport over soil surfaces, Catena, 141, 39-45, 2016.

Huang, S. L., Wan, Z. H., and Smith, P.: Numerical modeling of heavy metal pollutant transport-transformation in fluvial rivers: a review, Int. J. Sediment Res., 22, 16-26, 2007.

Kanazawa, Y. and Kamitani, M.: Rare earth minerals and resources in the world, J. Alloy. Compd., 408, 1339-1343, 2006.

Khan, A. M., Bakar, N. K. A., Bakar, A. F. A., and Ashraf, M. A.: Chemical speciation and bioavailability of rare earth elements (REEs) in the ecosystem: a review, Environ. Sci. Pollut. R., 126, https://doi.org/10.1007/s11356-016-7427-1, 2016.

Kynicky, J., Smith, M. P., and Xu, C.: Diversity of rare earth deposits: the key example of China, Elements, 8, 361-367, 2012.

Lambert, M. G., Devantler, B. P., Nes, P., and Penny, P. E.: Losses of nitrogen, phosphorus, and sediment in runoff from hill country under different fertiliser and grazing management regimes, N. Z. J. Agric. Res., 28, 371-379, 1985.

Lu, H. Z., Liang, Y., Cao, L. X., and Chen, L.: Water and soil loss research in rare earth tailing heap in southern Jiangxi, Soils, 47, 387-393 , 2015 (in Chinese with English Abstract).

Lu, R. K.: Soil and agro-chemical analysis, China Agricultural Scientech Press, Beijing, 2000.

Lü, Y., Fu, B., Chen, L., Liu, G., and Wei, W.: Nutrient transport associated with water erosion: progress and prospect, Prog. Phys. Geogr., 31, 607-620, 2007.

Ma, W., Li, Z., Ding, K., Huang, J., Nie, X., Zeng, G., Wang, S., and Liu, G.: Effect of soil erosion on dissolved organic carbon redistribution in subtropical red soil under rainfall simulation, Geomorphology, 226, 217-225, 2014.

Meng, L., Feng, Q., Wu, K., and Meng, Q.: Quantitative evaluation of soil erosion of land subsided by coal mining using RUSLE, Int. J. Min. Sci. Technol., 22, 7-11, 2012.

Ministry of Water Resources, PRC (MWR): National professional standards for classification and gradation of soil erosion (SL1902007), China Water\&Power Press, Beijing, 3-12, 2008 (in Chinese).

Mol, J. H. and Ouboter, P. E.: Downstream effects of erosion from small-scale gold mining on the instream habitat and fish commu- nity of a small Neotropical rainforest stream, Conserv. Biol., 18, 201-214, 2004.

Morgan, R. P. C.: Soil erosion and conservation, third edn., Blackwell Publishing, Oxford, 2005.

Nascimento, F. L., Boëchat, I. G., Teixeira, A. O., and Gücker, B: High variability in sediment characteristics of a Neotropical stream impacted by surface mining and gully erosion, Water Air Soil Poll., 223, 389-398, 2012.

Nie, S. W., Gao, W. S., Chen, Y. Q., Peng, S. U. I., and Eneji, A. E.: Review of current status and research approaches to nitrogen pollution in farmlands, Agric. Sci. China, 8, 843-849, 2009.

Ongley, E. D., Xiaolan, Z., and Tao, Y.: Current status of agricultural and rural non-point source pollution assessment in China, Environ. Pollut., 158, 1159-1168, 2010.

Ojeda, G., Tarrasón, D., Ortiz, O., and Alcaniz, J. M: Nitrogen losses in runoff waters from a loamy soil treated with sewage sludge, Agr. Ecosyst. Environ., 117, 49-56, 2006.

Packey, D. J. and Kingsnorth, D.: The impact of unregulated ionic clay rare earth mining in China, Resour. Policy, 48, 112-116, 2016.

Palis, R. G., Okwach, G., Rose, C. W., and Saffigna, P. G.: Soil erosion processes and nutrient loss. 1 . The interpretation of enrichment ratio and nitrogen loss in runoff sediment, Soil Res., 28, 623-639, 1990.

Parsons, A. J., Brazier, R. E., Wainwright, J., and Powell, D. M.: Scale relationships in hillslope runoff and erosion, Earth Surf. Proc. Land., 31, 1384-1393, 2006.

Pascaud, G., Boussen, S., Soubrand, M., Joussein, E., Fondaneche, P., Abdeljaouad, S., and Bril, H.: Particulate transport and risk assessment of $\mathrm{Cd}, \mathrm{Pb}$ and $\mathrm{Zn}$ in a Wadi contaminated by runoff from mining wastes in a carbonated semi-arid context, J. Geochem. Explor., 152, 27-36, 2015.

Peng, D. S.: Soil erosion features and prevention technologies of Thulium Mine in south part of Jiangxi Province, Subtrop. Soils Water Conserv., 17, 14-15, 2005 (in Chinese with English Abstract).

Razo, I., Carrizales, L., Castro, J., Díaz-Barriga, F., and Monroy, M.: Arsenic and heavy metal pollution of soil, water and sediments in a semi-arid climate mining area in Mexico, Water Air Soil Poll., 152, 129-152, 2004.

Reddy, K. R. and Patrick, W. H.: Nitrogen transformations and loss in flooded soils and sediments, Crit. Rev. Environ. Sci. Technol., 13, 273-309, 1984.

Richardson, C. W. and King, K. W.: Erosion and nutrient losses from zero tillage on a clay soil, J. Agric. Eng. Res., 61, 81-86, 1995.

Riley, S.: Aspects of the differences in the erodibility of the waste rock dump and natural surfaces, Ranger Uranium Mine, Northern Territory, Australia, Appl. Geogr., 15, 309-323, 1995.

Schlesinger, W. H., Ward, T. J., and Anderson, J.: Nutrient losses in runoff from grassland and shrubland habitats in southern New Mexico: II. Field plots, Biogeochemistry, 49, 69-86, 2000.

Schoumans, O. F., Chardon, W. J., Bechmann, M. E., GascuelOdoux, C., Hofman, G., Kronvang, B., Rubæk, G. H., Ulén, B., and Dorioz, J. M.: Mitigation options to reduce phosphorus losses from the agricultural sector and improve surface water quality: a review, Sci. Total Environ., 468-469, 1255-1266, 2014. 
Sharpley, A. N.: The selection erosion of plant nutrients in runoff, Soil Sci. Soc. Am. J., 49, 1527-1534, 1985.

Sharpley, A. N., Smith, S. J., Jones, O. R., Berg, W. A., and Coleman, G. A.: Transport and prediction of sulfate in agricultural runoff, J. Environ. Qual., 20, 415-420, 1991.

Slattery, M. C. and Burt, T. P.: Particle size characteristics of suspended sediment in hillslope runoff and stream flow, Earth Surf. Proc. Land., 22, 705-719, 1997.

Tian, Y. H., Yin, B., Yang, L. Z., Yin, S. X., and Zhu, Z. L.: Nitrogen runoff and leaching losses during rice-wheat rotations in Taihu Lake region, China, Pedosphere, 17, 445-456, 2007.

Tse, P. K.: China's rare earth industry: USGS open file report 2011-1042, 11 p., available only online: http://tvernedra.ru/ RedkozemKit.pdf (last access: 31 May 2016), 2011.

Wallach, R., Jury, W. A., and Spencer, W. F.: The concept of convective mass transfer for prediction of surface-runoff pollution by soil surface applied chemicals, Trans. ASAE, 32, 906-912, 1989.

Weng, Z., Mudd, G. M., Martin, T., and Boyle, C. A.: Pollutant loads from coal mining in Australia: discerning trends from the National Pollutant Inventory (NPI), Environ. Sci. Policy, 19, 7889, 2012.

West, T. O. and Wali, M. K.: A model for estimating sediment yield from surface-mined lands, Int. J. Surf. Min. Reclam. Environ., 13, 103-109, 1999.

$\mathrm{Wu}, \mathrm{Y}$. and Chen, J.: Modeling of soil erosion and sediment transport in the East River Basin in southern China, Sci. Total Environ., 441, 159-168, 2012.
Yang, S. T.: Fast greening control technology discussion in rare earth tailing, Subtrop. Soils Water Conserv., 21, 61-63, 2009 (in Chinese with English Abstract).

Yang, X. J., Lin, A., Li, X. L., Wu, Y., Zhou, W., and Chen, Z.: China's ion-adsorption rare earth resources, mining consequences and preservation, Environmental Development, 8, 131136, 2013.

Young, R. A. and Onstad, C. A.: Characterization of rill and interrill eroded soil, Trans. Am. Soc. Agric. Eng., 21, 1126-1130, 1978.

Zhang, Q., Liu, D., Cheng, S., and Huang, X.: Combined effects of runoff and soil erodibility on available nitrogen losses from sloping farmland affected by agricultural practices, Agr. Water Manage., 176, 1-8, 2016.

Zhang, X. C. and Shao, M. A.: Soil organic matter and nitrogen losses by erosion in little catchment model as effected by vegetation coverage, Acta Agrestia Sinica, 8, 198-203, 2000 (in Chinese with English Abstract).

Zheng, F. L., He, X. B., Gao, X. T., Zhang, C. E., and Tang, K. L.: Effects of erosion patterns on nutrient loss following deforestation on the Loess Plateau of China, Agr. Ecosyst. Environ., 108, 85-97, 2005.

Zheng, Y., Luo, X., Zhang, W., Wu, X., Zhang, J., and Han, F.: Transport mechanisms of soil-bound mercury in the erosion process during rainfall-runoff events, Envrion. Pollut., 215, 10-17, 2016.

Zhou, D., Luo, C.G., Su, J., and Luo, X. P.: Soil ecological restoration in ionic rare earth mining area, Metal Mine, 460, 103-109, 2014 (in Chinese with English Abstract). 